\section{Search for consensus on genetic engineering}

Sir - If the Genschutz-Initiative (geneprotection initiative) is accepted by a majority of Swiss voters in June (see Nature 391, 312; 1998), a constitutional change will lead to the strictest regulation of gene technology anywhere in the world. It may appear astonishing that the Swiss - whose wealth depends so heavily on research and development leading to new technologies - would accept such restrictions on the use of what is likely to become the key technology of the future.

Perhaps a more prudent implementation of gene technology, and a better prepared social and ethical discussion of its desirability, could have prevented the successful signature campaign for such a restrictive initiative. (In Switzerland, at least 100,000 voters have to support an initiative to have a referendum on a constitutional change.) But the pace at which applications of gene technology are implemented makes either of these difficult to achieve. Indeed, it is questionable whether existing political instruments are adequate to conduct an effective discussion of such new technologies.
The only reasonable alternative is to intensify the social and political discussion. For this purpose, new institutions are needed, and experts trained to communicate information to lay people about new technologies and their potential implications in a neutral environment, without hierarchical structures and patronizing attitudes.

It also requires flexible political instruments, such as 'consensus conferences', in which groups whose members are selected as representative of age, gender, education and occupational skills cross-examine expert witnesses and discuss such topics. Although their conclusions — often surprisingly sophisticated, despite a short preparation time - are not legally binding, they can serve as a useful political barometer to politicians and institutional decisionmakers.

'Consensus conferences' are not a solution to all political problems. But they could be an important instrument in the future, particularly in Switzerland, where there has so far been reluctance to use such political instruments.

\section{Michael Altmann}

Institut für Biochemie

und Molekularbiologie,

Universität Bern, Bühlstr. 28,

3012 Bern, Switzerland

e-mail:michael.altmann@mci.unibe.ch

\section{Growing benefits of biotechnology}

Sir - In his review of my book The Doubly Green Revolution ${ }^{1}$, N. W. Simmonds asserts that biotechnology's "plant breeding achievements so far are nil". This is simply not true. Even the average supermarket shopper is aware that the products of genetically engineered crops are on the shelves. Last year, more than 20 million acres of such crops were harvested in the United States, and there have been some significant achievements in developing countries ${ }^{2}$.

Tissue-culture techniques in China and South Korea have produced several new rice varieties; one, La Fen Rockefeller, is giving up to $25 \%$ higher yields. Transgenic rices are now available incorporating resistance to insects, bacterial blight, rice stripe virus and hoja blanca virus. Molecular markers have been used to incorporate multiple resistance genes in rice in China, India and Colombia. None of this would have been possible without biotechnology.

\section{Gordon Conway}

Sussex House, University of Sussex,

Falmer, Brighton BN1 9RH, UK

1. Simmonds, N.W. Nature 391, 139 (1998).
2. James, C. ISAAA Briefs No. 5 (Intl Service for the Acquisition of
Agri-Biotech Applications, Ithaca, New York, 1997). 